\title{
Appel à rédacteur.trice.s invité.e.s / Call for Guest Editors
}

\section{Date limite : 1er novembre 2020}

Avez-vous en tête une thématique stimulante pour un numéro exceptionnel? La revue Simone de Beauvoir Studies est à la recherche d'un.e ou des rédacteur.trice.s invité.e.s pour son prochain numéro spécial $(S d B S$ 33.2, octobre 2022). Le comité éditorial encourage non seulement les propositions d'approches ou de thématiques portant spécifiquement sur les écrits de Beauvoir, mais également celles qui entrent en dialogue avec son héritage. Celles-ci peuvent avoir trait, par exemple, aux études sur le genre (gender studies), au féminisme, à la sexualité, au corps ou au handicap; aux études interculturelles ou postcoloniales, à la politique mondiale ; à la théorie littéraire, à la correspondance ou aux Mémoires. La revue $S d B S$ accepte les propositions de numéro spécial émanant de particuliers ainsi que d'équipes composées de chercheur.se.s issu.e.s de différents pays. Pour découvrir comment soumettre une proposition, nous vous invitons à consulter la page suivante: www.brill.com/sdbs.

\section{Deadline: November 1, 2020}

Do you have an idea for an exciting theme that would make for an outstanding journal issue? Simone de Beauvoir Studies is seeking one or more guest editors for its next special issue ( $S d B S$ 33.2, October 2022). $S d B S$ not only encourages proposals for themes that directly address Beauvoir's writings, but also for those that do not treat Beauvoir's writings per se but are nonetheless in conversation with her legacy such as gender studies, feminism, sexuality studies, disability studies, critical race theory, global politics, twentieth-century history, posthumanism, literary theory, and autobiography. $S d B S$ welcomes proposals from individuals and from teams comprised of researchers and writers from different countries, and other pairings that harbor multiple perspectives. For more information, please see "Guest Editor Proposal Guidelines" at www.brill.com/ sdbs. 